\title{
SALINITY AND ISOTOPE ANALYSIS OF SOME MULTI-YEAR LANDFAST SEA-ICE CORES, NORTHERN ELLESMERE ISLAND, CANADA
}

\author{
by \\ Martin O. Jeffries \\ (Geophysical Institute, University of Alaska, Fairbanks, Alaska 99775-0800, U.S.A.) \\ and \\ H. Roy Krouse \\ (Department of Physics, University of Calgary, Calgary, Alberta T2N 1N4, Canada)
}

\begin{abstract}
The salinity and isotope $\left({ }^{18} \mathrm{O},{ }^{3} \mathrm{H}\right)$ content of multi-year landfast sea-ice (MLSI) cores from northern Ellesmere Island, Canada, are examined. Salinity ranges from $0.01 \%$ to $4.54 \%$ and $\delta^{18} \mathrm{O}$ ranges from $-23.8 \%$ to $+0.7 \%$. Salinity and $\delta^{18} \mathrm{O}$ are linearly related, and tritium values generally exceed natural background levels. The results are evidence of ice growth associated with fresh-water / sea-water stratification below the ice. Salinity variations are cyclic and indicate a mean annual bottom accretion rate of $0.33-0.5 \mathrm{~m} \mathrm{a}^{-1}$. Rather than signifying downward percolation of melt water from the surface, the ice $\delta$ values are a proxy measure of variations in salinity and ${ }^{18} \mathrm{O}$ content of the water below the ice. Annual salinity layers are preserved in the absence of significant brine movement and ice deformation. The fast-ice environment appears to favour the maintenance of water stratification and growth of annual layers. It is suggested that ice growth in this environment is somewhat independent of thermodynamic sea-ice growth models; instead, ice growth by a double-diffusion process might account for the growth of MLSI beyond thicknesses normally encountered in undeformed multi-year pack-ice floes.
\end{abstract}

\section{INTRODUCTION}

Annual salinity layers in sea ice are attributed to ice growth which is associated with fresh-water/sea-water stratification beneath pack-ice floes (Cherepanov 1957, Untersteiner and Badgley 1958, Schwarzacher 1959, Martin and Kauffman 1974). Deuterium variations in pack-ice floes indicated a similar process, but it was noted that, because of mixing, stratification might not persist long enough for annual layers to form (Friedman and others 1961). This suggests that a stable fast-ice environment is more favourable for the maintenance of stratification and annuallayer growth.

The fast-ice fringe off the north coast of Ellesmere Island includes ice shelves and multi-year landfast sea ice (MLSI). Having grown to replace the ice shelf lost by calving, large areas of MLSI have remained in place for many years (Jeffries and Serson 1986). Since 1982 we have drilled a number of cores in MLSI (Fig.1), and salinity and isotope $\left({ }^{18} \mathrm{O},{ }^{3} \mathrm{H}\right)$ contents have been measured. In this paper we report the results of the analysis of five particular cores (Fig.1) in which annual salinity layers are evident and $\delta^{18} \mathrm{O}$ values indicate a considerable fresh-water input to the system. The results are discussed with reference to annual layers and ice growth, and variations in water stratification beneath the ice. Field and analytical techniques are described elsewhere (Jeffries and others 1988, this volume).

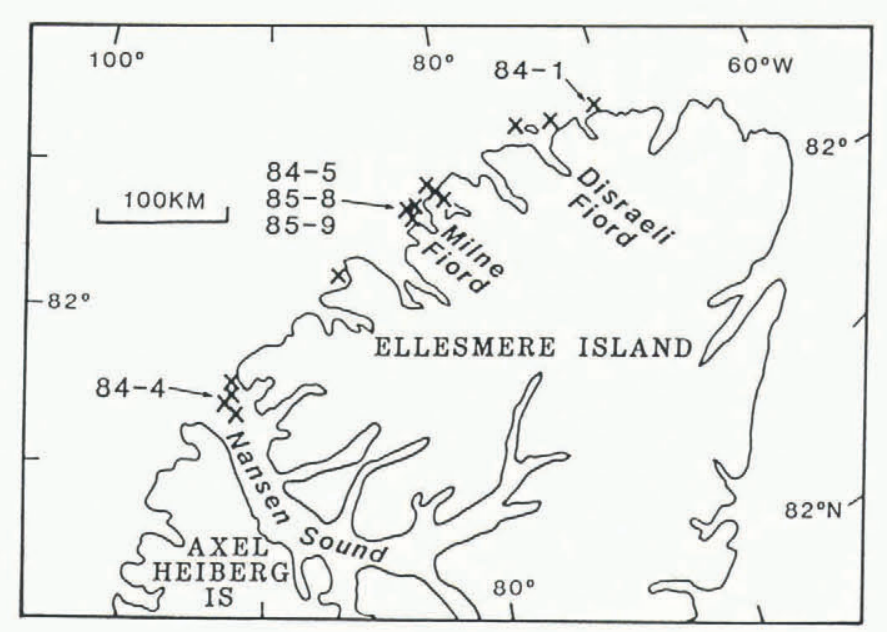

Fig.1. Location map of ice cores drilled in multi-year landfast sea ice off the north coast of Ellesmere Island. Those considered in this paper are identified by core number.

\section{RESULTS}

Salinity and $6^{18} \mathrm{O}$

Data are presented in Table I. The $\delta$ values are expressed relative to the Standard Mean Ocean Water (SMOW), which approximates the mean oxygen and hydrogen isotopic composition of the oceans and has a value very close to zero per mil (Craig 1961). MLSI \& values show considerable deviation from SMOW, indicating a meteoric-water input to the system. The term "meteoric water" refers to water that has recently been involved in atmospheric circulation.

The ice cores drilled in 1984 were cut into $50 \mathrm{~mm}$ increments, whereas the 1985 ice cores were cut into $100 \mathrm{~mm}$ increments. The salinity of every ice sample was measured, whereas only about half the ice samples were analyzed for their ${ }^{18} \mathrm{O}$ content. Salinity and $\delta^{18} \mathrm{O}$ profiles for cores 85-8 and 85-9 are shown in Figure 2. The continuous profiles of consecutive salinity values show a marked regularity that was also present in cores $84-1,84-4$, and $84-5$. It is probable that these regular fluctuations are annual ice layers. Since our main purpose is to discuss the formation and significance of these layers, a detailed description of the data analysis will not be given. It is sufficient to note that spectral analysis of the cores revealed cycles of $0.33 \mathrm{~m}(84-4)$ and $0.5 \mathrm{~m}(84-1,85-8,84-5$, and $85-9$ ). Furthermore, the annual-layer spacing remains quite constant throughout the ice; there is no marked decrease in spacing as ice depth increases.

Cores 84-5 and $85-8$ were drilled $10 \mathrm{~m}$ apart in the 
Jeffries and Krouse: Salinity and isotope analysis

TABLE I: SALINITY AND $\delta^{18} \mathrm{O}$ DATA FOR MULTI-YEAR LANDFAST SEA-ICE CORES

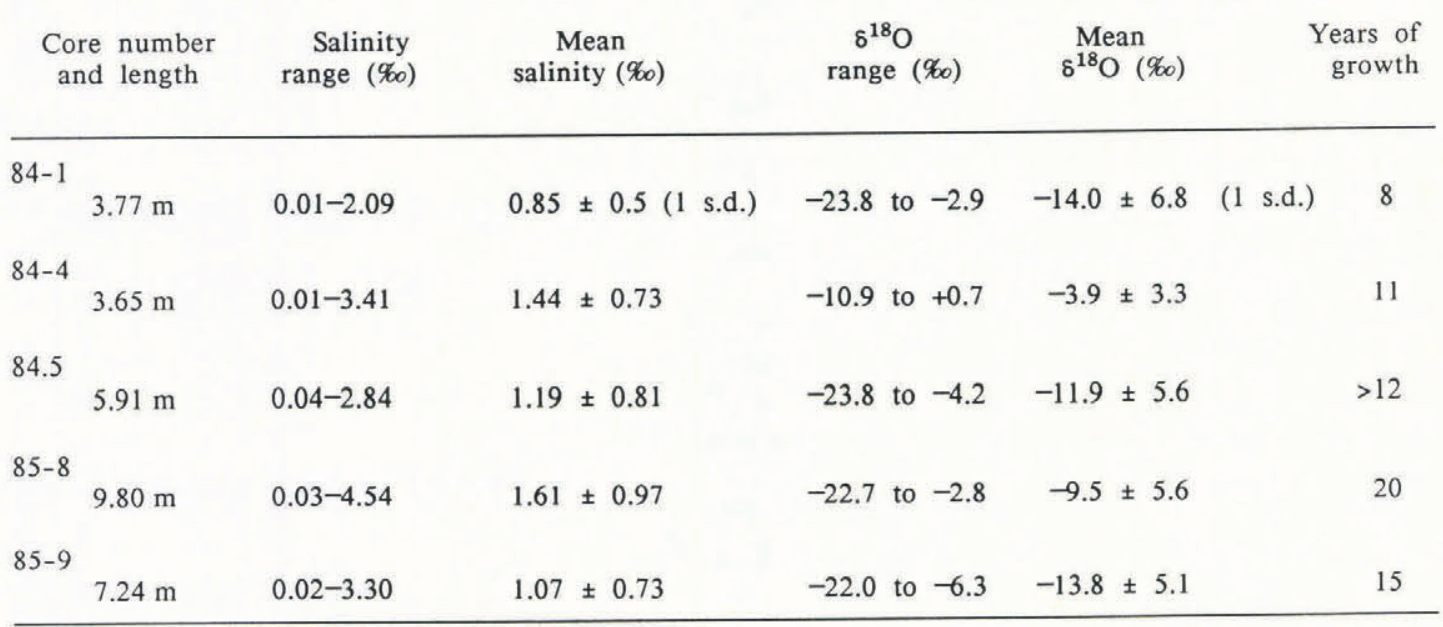

Note: All cores except $84-5$ were drilled through the ice.

The number of years of ice growth in $84-5$ is, therefore, a minimum.

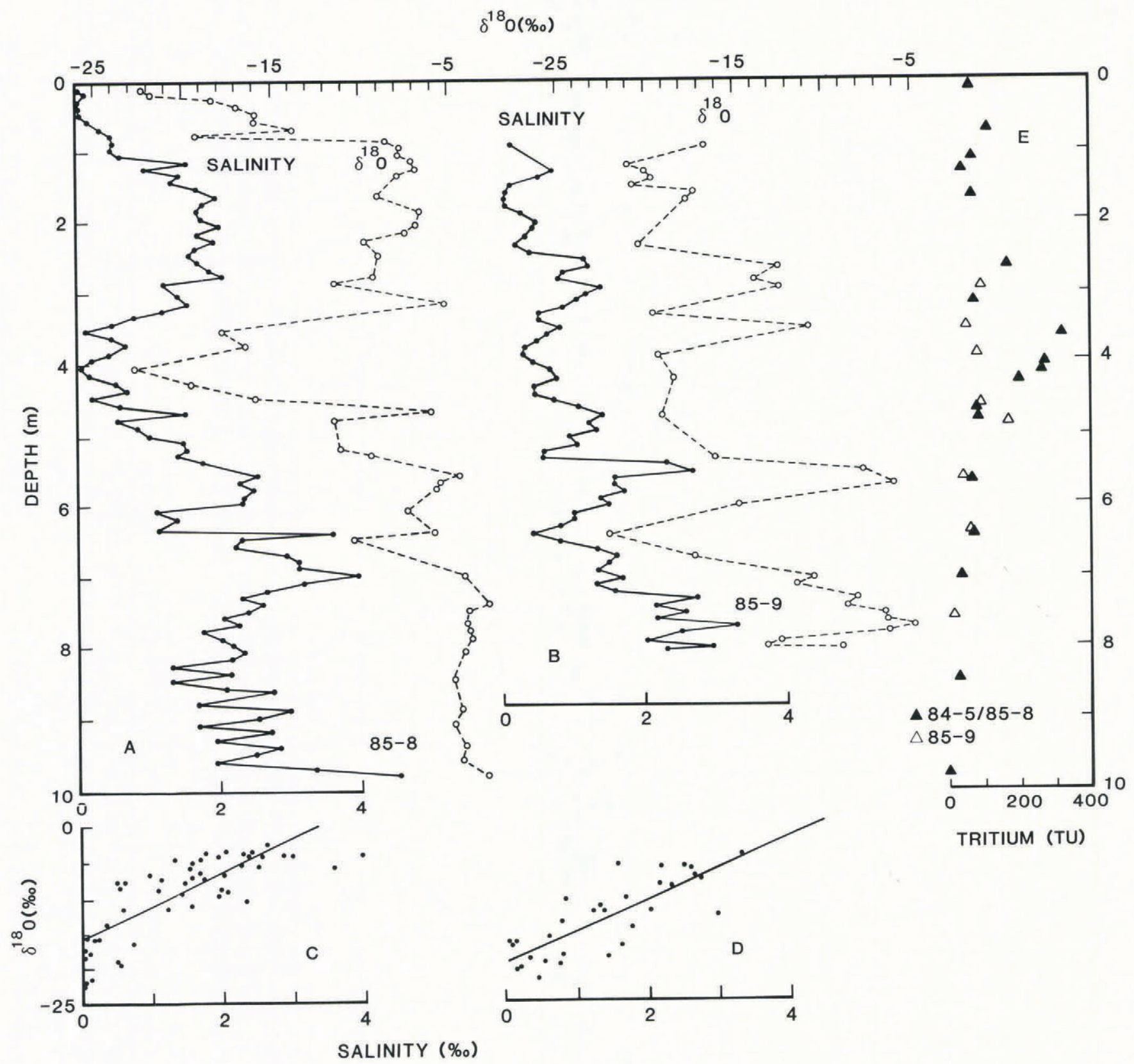

Fig.2. (a) and (b): salinity and $\delta^{18} \mathrm{O}$ profiles in ice cores $85-8$ and $85-9$. (c) and (d): $\delta^{18} \mathrm{O}$ salinity diagrams for ice cores $85-8$ and $85-9$. (e): tritium activity in ice cores $84-5 / 85-8$ and $85-9$. Core $85-8$ was drilled in a hummock at an elevation $0.82 \mathrm{~m}$ higher than core $85-9$, which was drilled in the adjacent depression. The salinity and $\delta^{18} \mathrm{O}$ profiles have been plotted to allow for this difference. 
same hummock, but 84-5 was not drilled through the ice. Salinity and $\delta^{18} \mathrm{O}$ profiles of equivalent depths of the cores are very similar. Likewise, the magnitude of tritium variations is similar (Fig.2e).

Whereas the salinity profiles are made up of consecutive data points, the $\delta^{18} \mathrm{O}$ profiles are discontinuous. However, the isotope variations are similar in pattern to the salinity variations (e.g. Fig.2a and b). Linear regression of $\delta^{18} \mathrm{O}$ versus salinity reveals that the agreement between the two parameters is quite good (Table II; Fig.2c and d).

The range of salinity and $\delta$ values (Table I) exceeds the magnitude of short-term fluctuations. A typical half-cycle occurs between 3.75 and $4.06 \mathrm{~m}$ in core $85-8$ (Fig.2a). Here, salinity falls from 0.71 to $0.04 \%$ (range $0.67 \%$ ) and $\delta^{18} \mathrm{O}$ falls from -16.4 to $-22.7 \%$ (6.3\%o).

The salinity and $\delta^{18} \mathrm{O}$ fluctuations are common to each core, but do not always occur throughout the ice. In the lowermost part of core 85-8 (Fig.2a) salinity fluctuations are evident, yet $\delta$ values are almost homogeneous, with a mean value of $-3.9 \pm 0.6 \%$ ( 1 s.d.). A similar feature is not evident in the adjacent depression core (Fig.2b).

\section{Tritium}

Tritium was not measured in core $84-1$, but each of the other cores has high levels of tritium, exceeding natural background levels. A tritium profile for Milne Re-entrant (Fig.2e) shows tritium values of 1-340 TU; the high values are associated with the low-salinity / low- $\delta^{18} \mathrm{O}$ layer in cores $84-5$ and $85-8$. The inverse relationship between $8^{18} O$ and tritium is particularly strong where tritium values are low and $\delta$ values are more positive (Fig.3). Conversely, the relationship weakens as $\delta$ decreases and tritium increases.

\section{Ice texture}

Ice textures vary throughout the ice cores. In core 84-5/85-8, lake-ice-type textures are associated with the very low-salinity/low- $\delta^{18} \mathrm{O}$ ice at about $4 \mathrm{~m}$, whereas sea-ice textures are found in more saline ice with more positive $\delta$ values. A layer of skeletal crystals was evident at the very bottom of the cores, indicating that growth was in progress (Weeks and Anderson 1958).

\section{DISCUSSION}

Growth and preservation of annual layers and age of the ice

Briefly, the growth of annual layers in sea ice can be described as follows (cf. Weeks and Ackley 1982). Under stratified conditions beneath an ice floe, those ice crystals that form at the halocline float upward until the fresh water is filled with a mesh of fragile crystals. In turn, these crystals form a solid layer of fresh-water ice on the under-surface of the ice cover. A similar process is envisaged beneath MLSI and gives rise to a mean annual bottom accretion of $0.33-0.5 \mathrm{~m}$. These values are comparable with previous observations of annual-layer thickness in sea ice: $0.34 \mathrm{~m}$ (Cherepanov 1957), $0.46 \mathrm{~m}$ (Schwarzacher 1959),

TABLE II. CHARACTERISTICS OF THE LINEAR REGRESSION OF $\delta^{18} \mathrm{O}$ VERSUS SALINITY (S) OF MULTI-YEAR LANDFAST SEA-ICE CORES

Core No. of samples $\quad \begin{gathered}\delta \text { Intercept, } \\ \mathrm{S}=0\end{gathered} \mathrm{SS} / \Delta \delta \quad \begin{gathered}\text { Correlation } \\ \text { coefficient, } r\end{gathered}$

\begin{tabular}{lllll}
\hline $84-1$ & 31 & $-22.6 \%$ & 10.10 & 0.85 \\
$84-4$ & 37 & $-7.4 \% 0$ & 2.45 & 0.62 \\
$84-5$ & 71 & $-18.6 \%$ & 5.46 & 0.76 \\
$85-8$ & 51 & $-15.7 \%$ & 4.14 & 0.78 \\
$85-9$ & 33 & $-19.5 \%$ & 4.32 & 0.81 \\
\hline
\end{tabular}

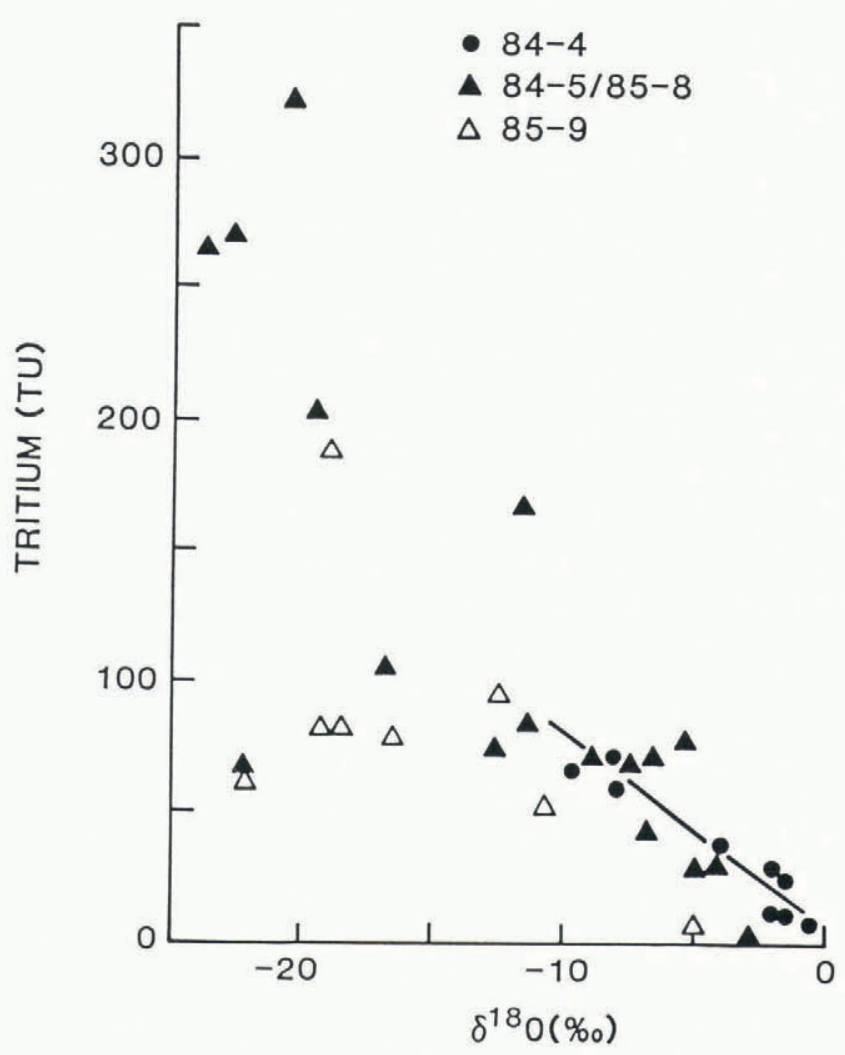

Fig.3. Scatter diagram for $\delta^{18} \mathrm{O}$ and tritium values. A regression line, $\delta^{18} \mathrm{O}=-0.16{ }^{3} \mathrm{H}+2.2 \% \circ(\mathrm{r}=-0.97)$, is plotted for ice core 84-4. The line illustrates the close relationship between more positive $\delta$ values and low tritium activity in all cores, in contrast to the greater scatter that exists in the case of more negative $\delta$ values.

$0.51 \mathrm{~m}$ (Friedman and others 1961). Although as much as $0.5 \mathrm{~m}$ of ice accretes at the bottom each year, this is not the net ice thickening. At the present time, the net surface-ice loss on Ward Hunt Ice Shelf amounts to about $100 \mathrm{~mm}$ of ice per annum (Hattersley-Smith and Serson 1970, Serson 1979). If we assume that this ice loss applies also to MLSI, then the net annual thickening is up to $0.4 \mathrm{~m}$.

Seasonal variations of $\delta^{18} \mathrm{O}$, specific electrical conductivity, and individual ions are commonly preserved in dry snow, firn, and ice (e.g. Epstein and others 1965, Langway and others 1977). In wet-snow areas, the seasonal variations are of ten homogenized or destroyed as melt water percolates and refreezes in the snow and firn (e.g. Arnason 1969). Gravity drainage and flushing of brine in sea ice (cf. Weeks and Ackley 1982) are analogous to melt-water percolation, yet there is no apparent homogenization of salinity and $\delta^{18} \mathrm{O}$ throughout much of the MLSI cores. This includes depression core 85-9 (Fig.2b), where the hydraulic head of the summer melt pool might be expected to influence brine loss strongly. It appears that brine movement in MLSI is either minimized or is not an effective homogenizing agent, perhaps because of low ice temperatures or variations in structural properties. In the top $0.5 \mathrm{~m}$ of ice (Schwarzacher 1959), and the whole ice column (Weeks and Ackley 1982), downward flushing of nearly pure surface melt water significantly reduced the ice salinity. This is not evident in MLSI. Annual salinity layers would probably also be lost if the ice had been deformed. Their preservation is evidence for the absence of deformation of MLSI and is consistent with a surface topography which shows few signs of old, weathered pressure ridges (Jeffries and Serson 1986).

The number of years of growth in each core was determined by dividing the core length by the relevant salinity cycle. The result corresponds to years of growth before the time the core was drilled (Table I). The ice has been growing for up to 20 years and continues to grow, viz. skeletal ice crystals. The number of years of growth gives a relative age that indicates the minimum time that 
the fast ice in a particular area has existed since calving. All of the ice cores post-date the atmospheric tritium peak of 1963 , as is reflected by the high ice-tritium values.

In the case of core $85-8$ the relative age is probably close to the absolute age. Aerial photographs indicate that a calving occurred between 1959 and 1974 from Milne Ice Shelf (Jeffries 1986). Our annual-layer counting method indicates that Milne Re-entrant began to grow in the winter of $1965-66$, thus the calving probably occurred during 1965 at the latest. Although this date is derived by a relatively simple method, it is corroborated to some extent by the tritium data. The high tritium value at $3.86 \mathrm{~m}$ (Fig.2e) corresponds to the summer of 1973. High tritium values are a function of low water salinity (Fig.3), but it is noted that in the early 1970s atmospheric tritium levels were unusually high, due to thermonuclear tests by France and particularly those in the Northern Hemisphere by the People's Republic of China.

Core 85-8 suggests that the ice began to grow in the hummock in 1965-66, whereas in the adjacent depression core $85-9$ (Fig.2a and b; Table I) growth supposedly began 5 years later. This discrepancy might be due to loss of layers by surface or bottom ablation of depression ice. If it is assumed that this did not occur in core 85-8, an absolute age of 20 years is suggested for Milne Re-entrant at the time of drilling.

\section{The water below MLSI}

During ice formation, oxygen-isotope fractionation of up to $3 \%$ occurs, with the ice being enriched in ${ }^{18} \mathrm{O}$ (O'Neil 1968). This alteration is small compared to the loss of brine from sea ice during growth. Oxygen-isotope ratios are conservative tracers and accurate proxies of the water below the ice at the time of growth. The water $\delta$ values (Table III) have been calculated from ice $\delta$ values (excluding the upper $0.5 \mathrm{~m}$ ), assuming a maximum fractionation of $3 \%$. Water stratification associated with ice-shelf dams also exists in this region and the following $\delta-S$ relationship has been established (Jeffries unpublished):

$$
\text { Salinity }=1.17 \delta^{18} \mathrm{O}+34.51 \%
$$

With this equation and the water $\delta$ values, the range of water salinities has also been calculated (Table III).

The range of $\delta$ and salinity values in Table III covers the lifetime of the ice and not seasonal variations. These will be discussed later. At one end of the range are the low salinity values associated with very negative $\delta$ values indicative of meteoric water. In this region, winter snow has a mean $\delta$ value of $-31.0 \%$ (Jeffries unpublished) and is the main source of tritiated fresh water that finds its way beneath the ice. At the other end of the spectrum, $\delta$ values approaching SMOW are associated with high salinities. Similar values are found in Arctic surface waters of the central Arctic Basin and indicate thorough mixing of fresh

TABLE III. RANGE OF $\delta$ VALUES AND SALINITY VALUES OF WATER BENEATH MLSI, DERIVED FROM ICE $\delta$ VALUES

Core Water $\delta$ range $(\%) \quad$ Water salinity range $(\%)$

\begin{tabular}{lrc}
\hline $84-1$ & $\begin{array}{r}-26.8 \text { to }-5.9 \\
(20.9)\end{array}$ & $\begin{array}{r}3.2 \text { to } 27.6 \\
(24.4)\end{array}$ \\
$84-4$ & -13.9 to -2.3 & 18.2 to 31.8 \\
$(11.6)$ & $(13.6)$ \\
$84-5$ & $-\begin{array}{r}-26.8 \text { to }-7.2 \\
(19.6)\end{array}$ & 3.2 to 26.1 \\
& $(22.9)$ \\
$85-8$ & $\begin{array}{r}-25.7 \text { to }-5.8 \\
(19.9)\end{array}$ & 4.4 to 27.7 \\
& -25.0 to -9.3 & $(23.3)$ \\
$85-9$ & $(15.7)$ & 5.3 to 23.6 \\
& & $(18.3)$
\end{tabular}

water and sea-water (Vetshteyn and others 1974). In our study, mixing is probably most thorough in Nansen Sound, where the range of water salinity/ $\delta$ values is not as extreme as elsewhere (Table III). The more thorough mixing in Nansen Sound probably accounts for the high $\delta^{-3} \mathrm{H}$ correlation (Fig.3), and the fresh water is derived almost wholly from snow-melt.

At the other locations, MLSI grows immediately adjacent to ice shelves which contain ice with very negative $\delta$ values, but negligible tritium content (Jeffries and others 1988, this volume). Melt water below MLSI at these locations is probably derived from two sources, snow- and ice-melt, each with similar $\delta^{18} \mathrm{O}$ values, but quite different tritium contents. Hence there is a greater scatter of tritium values associated with the most negtive $\delta$ values (Fig.3).

Seasonal fluctuations of water salinity and $\delta^{18} \mathrm{O}$ are not as extreme as the overall range of values in each core, as shown by the seasonal cycle at $3.75-4.06 \mathrm{~m}$ in core $85-8$. In this case the decrease in $\delta$ values in the ice corresponds to a winter-summer shift of water $\delta$ values from $-19.4 \%$ to $-25.7 \%$. From Equation 1 we obtain a water-salinity decrease of $7.4 \%$ : from 11.8 to $4.4 \%$. The magnitude of the seasonal salinity and $\delta^{18} \mathrm{O}$ variations below MLSI suggests two particular points about the nature and extent of the fresh-water layer. First, a low-salinity / low- $\delta$ layer is not completely dissipated at the end of summer, but can persist year-round, with only slight seasonal changes. Secondly, rather than being confined to inverted depressions under the ice, a continuous sheet of deep $(\geqslant 1.74 \mathrm{~m}$ in the case of cores $85-8$ and 85-9) low-salinity, low- $\delta$ water might extend deeper than under-ice keels, beneath MLSI. There is no other plausible explanation for the low-salinity / low- 8 layer in cores $84-5$ and $85-8$ (Fig.2a). However, there are times when the low-salinity/low- $\delta$ water layer is relatively shallow and the keels extend into sea-water, hence the homogeneous $\delta$ values at the bottom of core $85-8$.

\section{Thick sea-ice growth}

Undeformed multi-year pack-ice floes commonly have a steady-state thickness of between 2.5 and $5 \mathrm{~m}$ (Maykut and Untersteiner 1971). However, much thicker floes are found occasionally in the Arctic Ocean and it has been suggested that they probably originated from the north coast of Ellesmere Island (Walker and Wadhams 1979). Thus they were once MLSI or, as Wadhams (1981) prefers, "sikussak". Using a modified Maykut-Untersteiner model, with increased snow cover and no oceanic heat flux, Walker and Wadhams (1979) accounted for thick sea-ice growth on thermodynamic grounds alone. Our observations and data show that annual-layer spacing in MLSI remains quite constant with depth and that the annual layers are the result of ice growth associated with water stratification below the ice; hence at least some of the MLSI growth is independent of Maykut-Untersteiner-type sea-ice growth models. It is more probable that the growth of MLSI can be accounted for by a double-diffusion process similar to that described by Martin and Kauffman (1974). The annual transfer of melt water from the ice surface to a cold sink below the ice will lead to thick sea-ice growth over a relatively short period.

\section{CONCLUSION}

Salinity variations in MLSI are largely related to water-salinity variations below the ice. Salinity and $\delta^{18} \mathrm{O}$ values in the ice are linearly related and the water variations can be derived from ice $\delta$ values. Tritium and $\delta$ values indicate that snow-melt is the primary fresh-water source, whereas ice-melt is a secondary source. Seasonal variations of water salinity and $\delta^{18} \mathrm{O}$ can be related to snow and ice ablation.

The salinity and ${ }^{18} \mathrm{O}$ content of the water depends on the degree of mixing of melt water and sea-water. At times the water is saline and $\delta$ values are close to SMOW. At other times a deep layer of ${ }^{18} \mathrm{O}$-depleted fresh water can persist year-round, with only a slight seasonal change. This could only occur in a stable fast-ice environment where conditions are most favourable for the maintenance of under-ice water stratification. Under these conditions mean annual bottom accretion amounts to $0.33-0.5 \mathrm{~m} \mathrm{a}^{-1}$ and 
annual layers form in the ice. When surface ablation is taken into account, the total annual ice thickening amounts to $0.23-0.4 \mathrm{~m}$. Ice growth associated with under-ice water stratification is independent of Maykut-Untersteiner-type thermodynamic models and this might account for the growth of MLSI beyond thicknesses normally encountered in undeformed multi-year pack-ice floes.

The stability of MLSI is evident in its age, as much as 20 years of growth at a given location, and the preservation of annual layers in the absence of deformation. The ice $\delta$ values and salinity variations result from processes occurring beneath the ice, not at the surface. The preservation of annual salinity variations, therefore, suggests that brine movement, by fresh-water flushing or other means, is minimal. The reasons for this remain unclear. Before the growth, structure, and properties of MLSI are fully understood, many more cores must be drilled and examined. However, though the number of cores examined in this paper is few, the results suggest the benefits to be gained from isotope analysis of sea ice.

\section{ACKNOWLEDGEMENTS}

This paper was written at the Geophysical Institute, University of Alaska, with the support of the U.S. Department of Energy, Morgantown Energy Technology Centre. However, the work was initiated when one of us (MOJ) was a graduate student in the Department of Geography, University of Calgary, and was supported by PSCP (Director, G D Hobson), Defence Research Establishment Pacific, the Arctic Institute of North America, Gulf Canada, Dome Petroleum, and Petro-Canada. Field work was undertaken with the help of Harold Serson. The stable-isotope laboratory at the University of Calgary is supported by grants from NSERC Canada.

\section{REFERENCES}

Arnason B 1969 The exchange of hydrogen isotopes between ice and water in temperate glaciers. Earth and Planetary Science Letters 6(6): 423-430

Cherepanov N V 1957 Opredeleniye vozrasta dreyfuyushchikh l'dov metodom kristalloopticheskogo issledovaniya [Using the methods of crystal optics for determining the age of drift ice]. Problemy Arktiki 2: 179-184

Craig H 1961 Standard for reporting concentrations of deuterium and oxygen-18 in natural waters. Science 133(3467): 1833-1834

Epstein S, Sharp R P, Gow A J 1965 Six year record of oxygen and hydrogen isotope variations in South Pole firn. Journal of Geophysical Research 70(8): 1809-1814

Friedman I, Schoen B, Harris J 1961 The deuterium concentration in Arctic sea ice. Journal of Geophysical Research 66(6): 1861-1864

Hattersley-Smith G, Serson H V 1970 Mass balance of the Ward Hunt ice rise and Ice Shelf: a 10 year record. Journal of Glaciology 9(56): 247-252

Jeffries M O 1986 Ice island calvings and ice shelf changes, Milne Ice Shelf and Ayles Ice Shelf, Ellesmere Island, N.W.T. Arctic 39(1): 15-19

Jeffries M O Unpublished Physical, chemical and isotopic investigations of Ward Hunt Ice Shelf and Milne Ice Shelf, Ellesmere Island, N.W.T. (PhD thesis, University of Calgary, 1985)

Jeffries M O, Serson H V 1986 Survey and mapping of recent ice shelf changes and landfast sea ice growth along the north coast of Ellesmere Island, NWT, Canada. Annals of Glaciology 8: 96-99

Jeffries M O, Sackinger W M, Krouse H R, Serson H V 1988 Water circulation and ice accretion beneath Ward Hunt Ice Shelf (northern Ellesmere Island, Canada), deduced from salinity and isotope analysis of ice cores. Annals of Glaciology 10: 68-72

Langway C C Jr, Klouda G A, Herron M M, Cragin J H 1977 Seasonal variations of chemical constituents in annual layers of Greenland deep ice deposits. International Association of Hydrological Sciences Publication 118 (General Assembly of Grenoble 1975 - Isotopes and Impurities in Snow and Ice): 302-306

Martin S, Kauffman P 1974 The evolution of under-ice melt ponds, or double diffusion at the freezing point. Journal of Fluid Mechanics 64(3): 507-527

Maykut G A, Untersteiner N 1971 Some results from a time-dependent thermodynamic model of sea ice. Journal of Geophysical Research 76(6): 1550-1575

O'Neil J R 1968 Hydrogen and oxygen isotope fractionation between ice and water. Journal of Physical Chemistry 72(10): $3683-3684$

Schwarzacher W 1959 Pack ice studies in the Arctic Ocean. Journal of Geophysical Research 64(12): 2357-2367

Serson H V 1979 Mass balance of the Ward Hunt ice rise and Ice Shelf: an eighteen year record. Victoria, BC, Defence Research Establishment Pacific. Research and Development Branch (Technical Memorandum 79-4)

Untersteiner N, Badgley F I 1958 Preliminary results of thermal budget studies on Arctic pack ice during summer and autumn. In Arctic Sea Ice; Conference held at Easton, Maryland, February 24-27, 1958. Washington, DC, National Academy of Sciences - National Research Council: 85-95 (Publication 598)

Vetshteyn V Ye, Malyuk G A, Rusanov V P 1974 Raspredeleniye kisloroda-18 v vode tsentral'noy chasti Arkticheskogo basseyna [Oxygen-18 distribution in the central Arctic Basin]. Okeanologiya 14(4): 514-519

Wadhams P 1981 The ice cover in the Greenland and Norwegian seas. Reviews of Geophysics and Space Physics 19(3): $345-393$

Walker E R, Wadhams P 1979 Thick sea ice floes. Arctic 32(2): 140-147

Weeks W F, Ackley S F 1982 The growth, properties and structure of sea ice. CRREL Monograph 82-1

Weeks W F, Anderson D L 1958 An experimental study of strength of young sea ice. American Geophysical Union. Transactions 39: 641-647 